\title{
PRENATAL AND POSTNATAL DIAGNOSTICS PROBLEMS OF THE MOST COMMON SURGICAL CONGENITAL MALFORMATIONS OF NEWBORNS IN LATVIA
}

\author{
Zane Ābola*, Aigars Pētersons*, Daila Pugačevska**, Astra Zviedre**, \\ and Jana Lackaja* \\ * Rīga Stradiṇš University, Dzirciema iela 16, Rīga, LV-1007, LATVIA; \\ e-mail: abola.zane@gmail.com \\ ** Children`s Clinical University Hospital, Vienības gatve 45, Rĩga, LV-1004, LATVIA \\ Communicated by Andrejs Ërglis
}

\begin{abstract}
The most common surgical congenital malformations of newborns in Latvia are esophageal atresia (EA) with or without tracheoesophageal fistula (TEF), duodenal atresia (DA) and abdominal wall defects - gastroschisis $(G)$ and omphalocele $(O)$. Survival and quality of life of these patients depend on precise pre- and postnatal diagnosis, timely and qualified treatment, and presence of associated anomalies and prematurity. The aim of our study was to define prenatal and postnatal diagnostic problems of the most common surgical congenital malformations of newborns in Latvia. Data concerning pre- and postnatal diagnostics from case-records of patients treated in Children's Clinical University Hospital from 1998 till 2008 with esophageal atresia (58 patients), duodenal atresia (20 patients) and congenital abdominal wall defects - gastroschisis (17 patients) and omphalocele (28 patients) were analysed. Results showed that in case of EA prenatal USG was performed in $62 \%$ of expectant mothers and in neither case suspicion about EA was expressed. In all patients after birth diagnostic placement of nasogastric tube was performed. In approximately one-third catheter of bad opaqueness was used. Preoperative bronchoscopy and esophagoscopy in order to exclude upper tracheoesophageal fistula were performed in two patients from the analysed group. In $40 \%$ of cases DA was diagnosed in prenatal ultrasonography. $G$ was diagnosed prenatally in $29.4 \%$, O - only in $3.7 \%$.
\end{abstract}

Key words: congenital surgical malformations in newborns, prenatal and postnatal diagnosis, esophageal atresia, duodenal atresia, congenital abdominal wall defect.

\section{INTRODUCTION}

Approximately 3\% of human newborns present with congenital malformations (Nadler, 1986). Without surgical intervention, one-third of these infants would die since their malformations are not compatible with sustained life outside the uterus. In figures, this means that in Latvia nearly 200 children are born each year with a life-threatening malformation. Survival and quality of life of these patients depend on proper diagnostics, well-timed and qualified treatment, prematurity and presence of associated anomalies.

The most common pathologies which present imediately after birth and can be diagnosed prenatally are esophageal atresia (EA), duodenal atresia (DA) and congenital abdominal wall defects (AWD): gastroschisis (G) and omphalocele (O).

The incidence of EA in Latvia is approximately 1 in 5000 live births. DA is seen in 1 of 5,000-10,000 live births. Gastroschisis and omphalocele are among the most frequently encountered congenital anomalies in pediatric surgery. The combined incidence of these anomalies is 1 in 2,000 live births.
Due to the development of prenatal diagnostics, improvement of surgical techniques and pre- and postoperative intensive care, most newborns with these otherwise fatal congenital pathologies can be rescued by an operation in the neonatal period. For better treatment outcome proper prenatal and postnatal diagnostics is essential. In our country all neonatal surgical procedures are performed in the Children`s Clinical University Hospital in Rīga.

Esophageal and duodenal atresia, as well as congenital abdominal wall defects can and should be diagnosed prenatally. These malformations are best managed by appropriate medical and surgical therapy after maternal transport to Rìga and planned delivery at term.

Ultrasound testing has become a routine part of the prenatal evaluation of almost all pregnancies. Most defects can be reliably diagnosed in the late first or early second trimester. A mother who is carrying a foetus with esophageal atresia (EA) may have polyhydramnios, which occurs in approximately $33 \%$ of mothers with foetuses with esophageal atresia and distal tracheoesophageal fistula (TEF) and in 
virtually $100 \%$ of mothers with foetuses with esophageal atresia without fistula (Saxena and Geoffrey, 2008). Decrease or absence of stomach bubble is also a classical ultrasonographic feature in the foetus with EA.

Duodenal atresia is prenatally detected in $32-57 \%$ of patients (Grosfeld and Rescorla, 1993; Phelps et al., 1997). Sonographic features of duodenal obstruction - doublebubble sign - become apparent in the third trimester. Polyhydramnios develops in $32-59 \%$ of cases. In the presence of polyhydramnios, normal findings on ultrasonography of the foetus do not exclude duodenal atresia (Al-Salem et al., 1989; Grosfeld and Rescorla, 1993). Approximately 80\% of cases are prenatally diagnosed with confirmation following delivery (Phelps et al., 1997).

The unique anatomic characteristics of gastroschisis and omphalocele allow them to be identified and differentiated using prenatal ultrasound. Using a combination of maternal serum screening and ultrasound, the sensitivity and specificity for prenatal diagnosis of abdominal wall defects should approach 100\% (Lennon and Gray, 1999). Associated anomalies which are present in approximately 10 to $35 \%$ (Puri, 2003) of newborns with EA, DA and AWD can be diagnosed by ultrasound as well. It is important to remember that sonography is operator-dependent. The scope and reliability of the information obtained is directly proportional to the skill and experience of the sonographer.

Given its long record of safety, utility, and cost-effectiveness, ultrasound will remain the modality of first choice when screening the foetus. However, foetal magnetic resonance imaging (MRI) is beginning to fill a niche in situations where ultrasound does not provide enough information about the possible congenital malformation. Foetal motion once limited MRI's utility for imaging in the uterus, but today's ultrafast MRI techniques have all but eliminated that problem. New MRI technology enables images to be acquired in less than one second and provide multiplanar views that help physicians to more accurately make diagnoses. Such technology has led to increased usage of foetal MRI, for earlier diagnosis of conditions affecting the baby and has proven useful in planning foetal surgery and designing postnatal treatments (Harvey, 2005). Typical scenarios for foetal MRI are after a suspected anomaly was spotted with ultrasound and if the mother is at risk for a condition that cannot be visualised well with sonography.

In case of esophageal atresia and duodenal atresia proper postnatal diagnostics is important. Passing nasogastric tube if EA is suspected and plain chest and abdominal X-ray examination in vertical position is essential to make correct diagnosis of this malformation. Characteristically, the neonate born with esophageal atresia drools and has substantial mucus, with excessive oral secretions. If suckling at the breast or bottle is allowed, the baby appears to choke and may have difficulty maintaining an airway. Significant respiratory distress may result.

Symptoms of duodenal atresia commence within the first 24 hours after birth. However, patients may present hours or days after delivery. Sustained vomiting (bilious or nonbil- ious) is the most common symptom, occurring in approximately $85 \%$ of cases (Bailey et al., 1993). Nonbilious vomiting occurs when atresia is present above the papilla of Vater. Vomiting is associated with variable dehydration, changes in serum electrolytes, and weight loss.

In infants with gastroschisis the bowel should be inspected to ensure its blood supply is not compromised by twisting of the mesentery or constriction at the abdominal wall defect. If so, the defect should be treated immediately. The bowel should be wrapped in warm saline-soaked gauze (Suita et al., 2000). Newborns with gastroschisis and omphalocele should be placed in a temperature-controlled environment, as they lose a great deal of heat through the exposed bowel.

The perinatal management of these patients involves many different medical disciplines, such as obstetricians, sonographers, neonatologists, geneticists, pediatric surgeons and general practicioners. It is essential that the affected family can be managed using a team approach. Thus, the aim of our study was to determine prenatal and postnatal diagnostic problems of the most common surgical congenital anomalies of newborns in our country.

\section{MATERIALS AND METHODS}

In order to carry out descriptive clinical investigation, data concerning pre- and postnatal diagnostics from case-records of patients treated in the Children`s Clinical University Hospital from 1998 till 2008 with esophageal atresia (58 patients), duodenal atresia (20 patients) and congenital abdominal wall defects, gastroschisis (17 pts) and omphalocele (28 pts), were analysed. Statistical processing was performed by determination of the $95 \%$ confidence limit (95\% CI) using the programme CIA. For performing all investigations permission from the ethical committee of Pauls Stradiňs Clinical Hospital Support Foundation was received.

\section{RESULTS}

Esophageal atresia. Suspicion of EA not raised in a prenatal case. Prenatal USG was performed in $62 \%$ of cases; in $45 \%$ polihydramnion was diagnosed (Table 1). In all patients after birth diagnostic placement of nasogastric tube was performed. Nasogastric tubes of different materials were used. In 28 patients $\mathrm{X}$-ray examination with a nasogastric tube placed in the oral segment of atretic esophagus was performed. In approximately one-third of cases an opaque catheter was used, which is one of the reasons why diagnostics were not very effective (the relationship between oral segment of esophagus and vertebrae was not possible to detect). In four patients X-ray examination without placement of a nasogastric tube in oral segment of esophagus was performed (11.8\%). Water-soluble contrast media was used in two EA patients (5.9\%). Preoperative bronchoscopy and esophagoscopy in order to exclude upper tracheoesophageal fistula were performed in two patients from the analysed group. 
Table 1

PRENATAL DIAGNOSIS OF THE MOST COMMON SURGICAL CONGENITAL MALFORMATIONS

\begin{tabular}{l|c|c|c|c}
\hline & $\begin{array}{c}\text { Esophageal } \\
\text { atresia }\end{array}$ & $\begin{array}{c}\text { Duodenal } \\
\text { atresia }\end{array}$ & $\begin{array}{c}\text { Gastro- } \\
\text { schisis }\end{array}$ & $\begin{array}{c}\text { Ompha- } \\
\text { locele }\end{array}$ \\
\hline Prenatal ultrasonoscopy & $62 \%$ & $80 \%$ & $76 \%$ & $91 \%$ \\
Suspected pathology & $0 \%$ & $40 \%$ & $29,4 \%$ & $37 \%$ \\
Polyhydramnios & $45 \%$ & $45 \%$ & $47 \%$ & $11 \%$
\end{tabular}

Duodenal atresia. From 1998 till 2008, twenty patients with DA were treated. Eight patients were premature. In $40 \%$ of cases duodenal atresia was diagnosed in prenatal ultrasonography (Table 1). On the first day of life, 15 patients $(75 \%)$ presented with bilious vomiting, the other patients $(25 \%)$ had nonbilious vomiting. In more than one half of patients $(55 \%)$ DA was diagnosed using plain abdominal $\mathrm{X}$-ray examination in vertical position. In other cases (45\%) incomplete DA was diagnosed using upper GI contrast study. In six cases (30\%) Down syndrome and congenital heart disease were diagnosed.

Congenital abdominal wall defects. In approximately $76 \%$ of cases with gastroschisis and in $91 \%$ with omphalocele women during pregnancy underwent prenatal ultrasound screening. Gastroschisis was diagnosed only in five cases (29.4\%), omphalocele in only one case (3.7\%) (Table 1). Polyhydramnios and associated anomalies were diagnosed in three cases $(11 \%)$ - renal dysplasia, coarctation of aorta, multiple defects of atrium.

\section{DISCUSSION}

The diagnostic potentialities of congenital malformations in Latvia has improved rapidly over the last few years. Availability of prenatal ultrasonography, development of magnetic resonance imaging (MRI) by evolving ultrafast scanning techniques and possibility of education in leading institutions of Europe and world for obstetricians, sonographers, neonatologists, and pediatric surgeons make feasible well-timed and exact diagnosis of congenital surgical malformations.

Timely perfomed and correct surgical treatment of congenital anomalies depend very much on early and precise diagnostics of the pathology. It is proven that proper prenatal and postnatal diagnostic is a key to well-timed surgical and medical treatment; it makes recovery of the patient faster and cost-effective (Bittencourt et al., 2004).

In the last decade, in leading clinics of Europe and USA emphasis is placed on prenatal diagnostics. In Western countries prenatal sonography is performed in approximately $90 \%$ of expactant mothers; in Latvia, only in $62 \%$. By performing prenatal sonography, not only „main pathologies" like esophageal or duodenal atresia or congenital abdominal wall defects, but also associated congenital anomalies of other organ systems can be diagnosed. Prenatal diagnosis influences the place, timing and mode of delivery in cases of complicated congenital anomalies. Unfortu- nately, EA is not diagnosed prenatally in Latvia (in Western countries isolated EA prenatally is found in $95 \%$ of cases, and EA with TEF in approximately 35\%). In Latvia DA in prenatal sonography was diagnosed in $40 \%$ and polyhydramnios in $45 \%$ of pregnancies. Literature indicated that prenatal diagnostics of duodenal atresia using ultrasonography can be as high as 87\% (Gupta and Sumit, 2000; Lawrence et al., 2004) and polyhydramnios 75\% (Bambini, 2000; Gupta and Sumit, 2000; Sweed, 2003; Lawrence et al., 2004; Millar et al., 2005). Regarding congenital abdominal wall defects (both gastroschisis and omphalocele) prenatal diagnosis in Latvia is unsatisfactory. Only in $3.7 \%$ cases omphalocele was diagnosed prenatally and gastroschisis in 29.4\%. In comparison, positive results of prenatal sonography in cases of AWD in leading clinics of Europe are in reach 65 to 79\% (Henrich et al., 2008).

Admittedly, a small number of expectant mothers in Latvia undergo prenatal ultrasound screening. Prenatal diagnostic in Latvia should be improved. It would allow to plan place, time and mode of delivery, thus ensuring well-timed and qualified correction of congenital anomaly.

Comparing postnatal diagnostics of congenital surgical malformations of newborns in Latvia and various clinics abroad, the situation significantly differs. In Latvia in all newborns with EA, the nasogastric tube in the stomach is passed immediately after birth. In our work we established that in all 58 EA patients a nasogastric tube was passed in esophagus for diagnostic reasons. X-ray examination of EA is used in a raher small number of cases (80\%). It must be emphasised that X-ray examination of chest and abdomen in vertical position is mandatory for all EA patients. In Latvia until now preoperative bronchoscopy was performed in only two cases of EA. We underline that in leading Western countries operative correction of EA is started only after bronchoscopy is performed.

Case records of DA patients show that only $80 \%$ of patients arrived to the Children`s Clinical University Hospital in the first 24 hours of life. On the first day of life 15 patients (75\%) presented with bilious vomiting, which indicates to atresia below papilla of Vater. Literature from various pediatric surgery centres show that in $80 \%$ of DA patients there was bilious vomitting (Bambini, 2000; Gupta and Sumit, 2000; Sweed, 2003). In 38-55\% of patients with duodenal obstruction association with another significant congenital anomaly is seen (Gupta and Sumit, 2000; Harvey, 2005). Our study shows that associated anomalies were present in $30 \%$ of DA patients (congenital heart disease, renal dysplasia, Down syndrome). Also, data in the literature shows that approximately $30 \%$ of cases are associated with Down syndrome, and $23-34 \%$ of cases are associated with isolated cardiac defects. Almost in 50\% of cases duodenal atresia is associated with prematurity and low birth weight (Gupta and Sumit, 2000; Millar et al., 2005; Sweed, 2003).

Only approximately one-third (33\%) of patients with AWD were born in Riga. Others were transported to the Children`s Clinical University Hospital during the first 24 
hours of life. In Latvia omphalocele is an isolated anomaly was seen in $18.5 \%$ of cases, but in $81.5 \%$ associated anomalies were diagnosed. Data from other clinics shows that associated anomalies are present in cases of omphalocele in approximately $72 \%$ (Collins et al., 2007). $22 \%$ of omphaloceles diagnosed were of associated with congenital anomalies. Our data showed that $11 \%$ of patients with AWD had chromosomal anomalies, which is almost one half of the proportion mentioned in literature (Mann et al., 2008).

For more precise and well-timed pre- and postnatal diagnostics of congenital malformations MRI can be used. Until recently, the long acquisition times required for this investigation were not conductive to foetal imaging because foetal movements resulted in poor quality images. Obtaining adequate images with the traditional spin-echo technniques required foetal sedation or paralysis (Daffos et al., 1988). Within the development of ultrafast scanning techniques, the artifacts caused by foetal motion have almost been eliminated (Hubbard et al., 1999). MRIF now is an important part of prenatal diagnosis of congenital amomalies and can be of great value in doubtful and suspicious cases. Recently foetal MRI has become available also in Rīga, thereby also in our country in so called ,borderline cases" ultrasonoscopy should be followed by foetal MRI, especially in 2nd and 3rd trimester of pregnancy.

Although none of the technologies alone can provide $100 \%$ infallibe diagnosis. The management of patients with these congenital malformations is complex and multidisciplinary. It should be underlined that the affected family should be managed using a team approach, and that information and experience should be exchanged freely.

\section{ACKNOWLEDGEMENTS}

The work was supported by the National Research Programme in Medicine 2006-2009, project No. 6, "Decreasing children's mortality, increasing life expectancy and improving life quality - development of high-technology based diagnostic and treatment algorithms of inherited pathologies".

\section{REFERENCES}

Al-Salem, A.H., Khwaja, S., Grant, C., Dawodu, A. (1989). Congenital intrinsic duodenal obstruction: Problems in the diagnosis and management. J. Pediatr. Surg., 24(12), 1247-1249.

Bailey, P.V., Tracy, T.F. Jr, Connors R.H., et al. (1993). Congenital duodenal obstruction: A 32-year review. J. Pediatr. Surg., 28(1), 92-95.
Bambini, D.A. (2000). Pyloric and duodenal obstruction. In: Pediatric Surgery (pp. 254-259). Arensman, R.M. (ed.). Georgetown, Texas: Landes Bioscience.

Bitencourt, D.G., Barini, R., Marba, S., Sbragi, L. (2004). Congenital duodenal obstruction: Does prenatal diagnosis improve the outcome? Pediatr. Surg. Int., 20(8), 582-585.

Collins, S.R., Griffin, M.R., Arbogast, P.G. et al. (2007). The rising prevelance of gastroschisis and omphalocele in Tennessee. J. Pediatr. Surg., 42,1221-1224.

Daffos, F., Forestier, F., Mac Aleese, J., et. al. (1988). Fetal curarization for prenatal magnetic resonance imaging. Prenat. Diagn., 8, 312-314.

Grosfeld, J.L., Rescorla, F.J. (1993). Duodenal atresia and stenosis: Reassessment of treatment and outcome based on antenatal diagnosis, pathologic variance, and long-term follow-up. World J. Surg., 17(3), 301-309.

Gupta, D.K. Sumit, D. (2000). Duodenal atresia and stenosis. In: A Textbook of Neonatal Surgery (pp. 172-180). Gupta, D.K.(ed.). New Delhi: Modern Publishers.

Harvey, D. (2005). Fetal MRI: Seeing What Ultrasound Doesn't. Radiology Today, 6, 18 .

Henrich, K., Huemmer, H.P., Reingruber, B., Weber, P.G. (2008). Gastroschisis and omphalocele: Treatments and long-term outcomes. Pediatr. Surg. Int., 24, 167-173.

Hubbard, A.M., Harty, M.P., States, L.J. (1999). A new tool for prenatal diagnosis: Ultrafast fetal MRI. Semin. Perinatol., 23, 437-47.

Kimble, R.M., Harding, J., Kolbe, A. (1997). Additional congenital anomalies in babies with gut atresia or stenosis: When to investigate, and which investigation. Pediatr. Surg. Int., 12(8), 565-570.

Lawrence, M.J., Andrew Ford, W.D., Furness, M.E., Hayward, T., Wilson, T. (2004). Congenital duodenal obstruction: Early antenatal ultrasound diagnosis. Pediatr. Surg. Int., 16(5-6), 342-345.

Lennon, C.A, Gray, D.L. (1999). Sensitivity and specificity of ultrasound for the detection of neural tube and ventral wall defects in a high risk population. Obstert. Gynecol., 94, 562-566.

Mann, St., Blinman, Th.A., Wilson R.D. (2008). Prenatal and postnatal management of omphalocele. Prenatal Diagnosis, 28, 626-632.

Millar, A.J.W., Rode, H., Cywes, S. (2005). Intestinal atresia and stenosis. In: Pediatric Surgery (pp. 416-419). Ashraft, K.W. (ed.). Philadelphia: W.B. Saunders.

Sweed, Y. (2003). Duodenal obstruction. In: Newborn Surgery (pp. 423-433). Puri, P. (ed.). London: Arnold.

Phelps, S., Fisher, R., Partington, A. (1997). Prenatal ultrasound diagnosis of gastrointestinal malformations. J. Pediatr. Surg., 32(3), 438-440.

Puri, P. (ed.). (2003). Newborn Surgery. London: Arnold. 337 pp.

Reid, I.S. (1973). Biliary tract abnormalities associated with duodenal atresia. Arch. Dis. Child., 48(12), 952-927.

Saxena, A.K., Geoffrey, B., (2008). Esophageal Atresia With or Without Tracheoesophageal Fistula. Retrieved 22 April 2009, from http:// emedicine.medscape.com/article/935858

Suita, S., Okamatsu, T., Yamamoto, T. (2000). Changing profile of abdominal wall defects in Japan: Results of a national survey. J. Pediatr. Surg., 35, $66-71$.

Received 11 July 2009

\section{PRENATĀLĀS UN POSTNATĀLĀS DIAGNOSTIKAS PROBLĒMAS BIEŽĀKO ĶIRURG̣ISKO IEDZIMTO PATOLOG̣IJU DIAGNOSTIKĀ LATVIJĀ}

Biežākās ḳirurğiskās iedzimtās patolog̣ijas jaundzimušajiem ir barības vada atrēzija (BVA) ar vai bez traheoezofageālu fistulu, duodenāla atrēzija (DA) un iedzimti vēdera priekšējās sienas defekti - gastrošīze $(G)$ un omfalocēle (O). Šo pacientu izdzīvošana, izveseḷošanās un dzīves kvalitāte ir atkarīga no precīzas prenatālās un postnatālās diagnostikas, savlaicīgas un kvalificētas ārstēšanas, asociēto anomāliju klātbūtnes un jaundzimušā neiznēsātības. Darba mērkiis bija noskaidrot minēto patoloğiju prenatālās un postnatālās diagnostikas problēmas Latvijā. Tika apkopoti dati no Bērnu klīniskajā universitātes slimnīcā (BKUS) laika posmā no 1998. līdz 2008. gadam ārstēto pacientu medicīniskajām kartēm. Jāsecina, ka prenatālā biežāko kịurğisko malformāciju diagnostika Latvijā ir neapmierinoša — nevienā gadījumā prenatāli nav diagnosticēta BVA, O - 3,7\%, G un DA attiecīgi 29,4\% un $40 \%$ gadījumu. Attīstīto valstu klīnikās šie rādītāji atkarībā no patoloğijas ir 65-95\%. Asociēto anomāliju biežums mūsu valstī korelē ar datiem literatūrā. Arī minēto patoloǵiju postnatālā diagnostika ir jāpilnveido, piemēram, BVA gadījumā kā ,zelta standarts” ieviešama pirmsoperācijas bronhoskopija. 